\title{
The Success and Shortcomings of Democratic Development in Nigeria from 1960 to 1999: An Overview
}

\author{
Nwokeke P.Osinakachukwu (Corresponding author) \\ Dept. of Government and Civilization Studies, Faculty of Human Ecology \\ Putra University, Malaysia \\ Tel: 60-14-334-1857Ｅ-mail: ossypeters@yahoo.com
}

Jayum A Jawan

Dept. of Government and Civilization Studies, Faculty of Human Ecology

Putra University, Malaysia

Tel: 60-19-321-5897Ｅ-mail: jayum@putra.upm.edu.my

Ma'rof Redzuan

Dept. of Social and Development Sciences, Faculty of Human Ecology

Putra University, Malaysia

Tel: 60-12-348-4810 E-mail:marof@putra.upm.edu.my

\begin{abstract}
This paper examines democratic development in Nigeria between 1960 and 1999. It discusses various democracies and some of the shortcomings inherent in their implementations. This work adopts a qualitative approach using both content and historical analysis to analyze secondary sources gathered on both civilian and military regimes as they affected democratic performances in Nigeria. This paper aims at helping policy makers in carrying out policies that will help strengthen the electoral bodies/conducts, respect the rule of law/constitution, ensure good governance which will improve leadership qualities and cement democratic values in the nation hence evidence from findings indicate that democracy have failed to triumph in Nigeria due to reasons emanating from bad governance and lack of democratic values. The paper provides some plausible recommendations that will be of particular benefit to policy makers and to general interest of Nigeria if properly implemented.
\end{abstract}

Keywords: Democratic development, Governance, Military intervention, Ethnic politics

\section{Introduction}

This article covers all the various regimes since 1960 and 1999, starting from the two civilian/ democratic administrations and military interventions in the politics of Nigeria. The first phase will cover the first and second republics, Abubarka Tafawa Belewa/ Nnamdi Azikiwe (1960-1966), and Shehu Shagari (1979-1983).The second phase will discuss the various military interventions and military administrations as they disorganised democratic process ranging from Aguiy Ironsi (1966-1967), Yakubu Gowon (1967-1975),Murtala Mohammed (9175-1976),Olusegun Obasanjo (1976-1979),Muhammadu Buhari (1983-1985), Ibrahim Babangida (1985-1993), and Sani Abacha (1993-1998).

Nigeria has made huge effort to develop and sustain democracy since 1960 to 1999.In her quest for a stabilize and virile democracy, Nigeria has adopted parliamentary and presidential systems of governments, two party and multi-party systems, creation of various electoral bodies and managed some elections since 1960 to 1999. It is worthy to note that Nigerians vehemently supported their elite's quest for independence because they see political sovereignty as an engine to emancipate the people from colonial administration and a prelude for better change via equity and freedom to re-design their own political foundation and promote the interest of all the regions. Unfortunately, the first attempt full of hope and optimism dashed in utmost despair.

However, democratic development in Nigerian politics has suffered setbacks due to bad governance. Military regimes in Nigerian politics and civilian administrations have contributed immensely in thwarting the efforts made by patriotic Nigerians to ensure democratic development in her body polity. This article will carefully look into these various regimes to ascertain how they negate the chances of democratic development in Nigeria. Elections conducted under military and civilian regimes have not yielded the needed result, reasons emanating from negligence to the rule of law 
which is the foundation for conducting a free and fair elections, provision of equal participation and right to vote, respect to electoral laws and conducts. Since 1960 to 1999, the system has recorded various violations of human rights cum political assassinations and these have made some politicians or opposition members politically apathetic.

\subsection{Background of study}

Nigeria had their independence in 1960 and since then resorted to the adoption of democratic rule in her quest for a political environment that will accommodate all the 250 ethnic groups. Between 1960 and 1999, Nigeria have produced eleven Head of states, be it military or civilian rules. Military claimed that it was the inability of their civilian counterparts to restore the image of the polity in the early independence made them to come into power. It is unfortunate to note that from the period of 1960 before in 1966 the military intervened, all the elections and programmes carried out failed to institutionalize democratic development due to ethnic politics, corruption and electoral malpractices.

Authoritarian regimes over the years in Africa and Nigeria in particular have greatly affected the emergence of consolidated democracy. Butt and Metz (1996) agreed that military regimes have been a huge challenge to democracy in Africa and Nigeria in particular due to the way the regime hijacks power and as a result dominate the political process even under a democratic administration. Military regimes have undermined emergence of democracy in Nigeria as a result of counter coups, human right abuses and neglect of the constitution. The histories of Nigeria's general elections have woefully affected democratic development due to electoral malpractices.

\subsection{Nature of the problems}

Nigeria's democracy right from 1960 to 1999 has not been geared towards realizing the values, aspirations and the well being of the citizenry .Due to violation of human rights and incessant military coups that trampled some democratic governments in Nigeria, it alienate the people from democratic development process, the support needed to implement some political policies are absolutely lacking. Democratic elections in Nigeria since 1960 contradict the assertion of one of Nigeria's nationalist leaders. In the view of Awolowo (1966), a change in the country must be the responsibility of all Nigerians to make good choices in elections.

Democratic elections in Nigeria no longer represent the wish of the people rather it represents the interest of the ruling oligarchy. Representatives are handpicked through election rigging and other forms of manoeuvre which have led many politically apathetic in the democratic process of Nigeria's body polity. Though there is a semblance of democratic governance in Nigeria from the election conducted in the country in 1999 but this has not really transformed previous situations of politics of godfatherism and money, political assassinations, none adherence to the rule of law, ethnic and religious rivalries. From 1960 to 1999, military counter coups have marred the emergence of democracy and electoral malpractice and election rigging have hindered the success of democratic development if elections conducted so far are anything to go by. The nature at which elections are conducted these days in Nigeria have left many electorate show no interest in elections.

Omotola (2007) notes that current democratic practice in Nigeria does not indicate the presence of real democracy because of the shortcomings manifesting in lack of democratic dividends for the people partly due to the undemocratic and anti-people workings of the democratic governments and the questionable integrity of the electoral process producing the democratic governments, such that there is need to deepen the democratic experience by overcoming these shortcomings in order to ensure the sustenance of democracy .

\subsection{Principles of Democracy}

In the words of Diamond, Linz and Lipset, (1989), Sorensen, (1993) elements of democracy are: political participation of the citizens; competition among political agents, especially political parties; and the granting of a host of civil and political liberties, which include freedoms of expression, association and the press, sufficient to ensure the integrity of political competition and participation. Dahl (1991:72-75) identifies seven criteria that democracy must possess. These include: elected officials must be chosen and peacefully removed in frequent, fair and free elections from which coercion is none existent; control over government decisions about policy is constitutionally vested in elected officials; virtually all adults have the right to vote; most adults have the right to run for public office in these elections; citizens possess civil and political rights; there is easy access to information not monopolized by the state or a single group; there is an enforceable right to form and join political organizations including political parties and interest groups

\section{Democracy in Nigeria}

Judging from the ideal elements of democracy above, Nigeria's democracy could be said to have failed short of the standard. Some elected officials are not accountable to the people, there is no respect to the rule of laws, there is violation of human rights, failure to adhere to the constitution, lack of good governance, military interventions, 
electoral manipulations/riggings cum ethnic politics, government lack of legitimacy and sometimes obnoxious laws are taken against what are enshrined in the constitution. All these factors above have distorted the chances of democratic development Nigeria. In this work, our indices will be lack of governance, military intervention, electoral manipulations/riggings and ethnic politics.

After Nigeria's independence in 1960, the hope and aspiration of Nigerian to attain nationhood began to fade evident emanating from the election conducted after the departure of the colonial British. The two democratic regimes of the first and second republics were dents on democracy. As at this period, the concept of democracy in Nigeria context was seen as a miscarried concept analyzed only by the political elites as it suits their whims and caprices. This was shown in the election conducted in 1964 which witnessed a widespread election rigging / rampaging manipulations, military takeover of democratically elected government, political assassinations and imposition of candidates on the electorates.

Since the attainment of independence in 1960, Nigeria has had three failed democratic governments due to military coup. Five general elections were conducted by various federal electoral bodies, i.e. Federal Electoral Commission (FEDECO), National Electoral Commission (NEC) and Independent National Electoral Commission (INEC) in 1964, 1965, 1983, 1993 and 1999. These elections were marred by electoral fraud and massive riggings. In 1993, Nigeria conducted the most free and fairest election that the international and local observers declared to be free and fair but unfortunately, the election was annulled by the government in power.

Political assassination emerged in Nigerian politics since October 19, 1986. Late Senior Advocate of Nigeria, Gani Fawehinmi described the state of assassination in Nigeria as: What we have been witnessing recently is not democracy by politicians, but a mindless display of craziness by members of the political class, and unless quickly checked, the democratic edifice will surely collapse and we would have ourselves to blame for the unprecedented flow of blood that will follow (Ajani, 2001). Joshua Yohanna, National Secretary of the Alliance for Democracy reports, "the adoption of murder by some politicians as means of settling misunderstanding or eliminating of opponents can best be described as barbaric ungodly, and monumental waste" ( Alliance for Democracy,2005:3). (Note 1).

\subsection{Civilian Regimes and Democracy}

The two democratic regimes of the first and second republics cannot be completely excused. Thus, the concept of democracy in Nigeria becomes a miscarried concept analyzed only by the power brokers as it satisfies their interest. This evident is shown in the election conducted in 1964 which accompanied a widespread ethnic politics, election rigging and rampaging manipulations.

Addressing the kind of politics played in this era, Uwazurike, Akinola (1989) described the First Republic as:

Severely limited in their capabilities to integrate the components of that great diversity of societies known as Nigeria. The NPC was the party of the Hausa-Fulani-Kanuri in the North, and did not extend its membership to the South; The AG more or less represented the Yorubas in the West; while the NCNC drew its support largely from the Ibos in the East (p.114)

Northern People's Congress (NPC) wanted party dominant democratic order for the ruling party (NPC) and used every plot to achieve this aim. Agbaje \& Adejumobi (2006) note that in 1964/65, the Northern Peoples Congress's (NPC's) desperate manipulation of the electoral process to monopolise political power in western Nigeria, using the Nigerian National Democratic Party (NNDP) as its proxy, resulted in political chaos that eventually collapsed the first republic.

After the general election in 1964, there were cases of manipulations in the western region between Chief Samuel Akintola of Nigerian National Democratic Party (NNDP) and Chief Obafemi Awolowo of Action Group (AG). So, fresh election was scheduled for the two parties in 1965.

The 1965 western region election also witnessed that electoral officers were accused of colliding with a favoured political party (NNDP) in the region to disallow electorates from the opposing party, Action Group (AG) from filling their allocated nomination papers. Dudley (1981), Anifowose (1982); Post and Vickers (1973) summarized: Akintola and his party (NNDP), with the federal government's support, carried out a staggeringly horrific rigging machinery, thuggery, obstruction and punitive control to give NNDP an overwhelming victory.

In the western region, the popular party was Action Group (AG).The people of the region took Chief Obafemi Awolowo as their political godfather and resolved to deliver the region for his party. They rallied round against Chief Samuel Akintola who is also a westerner and a flagbearer of Nigerian National Democratic Party (NNDP) but had a power tussle with Chief Obafemi Awolowo. The ruling party (NPC) supported Akintola via massive rigging and voted Chief Obafemi Awolowo's Action Group (AG) out. Dudley (1982) notes that the Deputy Leader of the NNDP and also Deputy Premier of the west, had in fact said before the elections that whether the electorate voted for the NNDP or 
not, NNDP would win the election. Democracy champions legitimacy but from the supportive role the ruling political party (NPC) played in imposing Akintola and his party (NNDP) on the West, the Northern People's Congress (NPC) lacked legitimacy in the West and so was unable to restore social order within the West. Even the Nigerian National Democratic Party which won the elections in the West also lacked the people's support in the area because of the manner in which the elections were won and lost.

There was disappointment among AG members as their attempt to vote Akintola and his party out of office failed, they resorted to widespread violence in many parts of the regions and the country, which resulted into one of the reasons that necessitated for the military takeover of government in January 15, 1966 and this ended the first democratic experience in Nigeria.

In fact, the first republican government did not give room for opposition party. Public policies were performed without considering the opinion of the opposition party and when it was obvious that the government could not get away with it, measures were adopted to eliminate the opposition party of the Action group of Nigeria. However, this period lacked full consideration for the principles of democracy (even as the political leaders neglected the well-being of the people for selfish purposes).

The second republic in 1979 came up with a constitution (1979 constitution) that ushered in various political arrangements to take back the country to a civilian democratic administration after nine years (1966-1975) of military rule.

The presidential system of government that provided for the office of an executive president (Shehu Shagari) was widely accepted as the best option for the people of Nigeria. The election conducted in 1979 was the second immediate testing ground for democracy after a thirteen-year military administration that lasted from 1966-1979. The election was contested by five different political parties namely; Nigerian Peoples Party (NPP) This party won most in the Igbo-speaking areas; Unity Party of Nigeria (UPN) dominated Yoruba-speaking areas; Peoples' Redemption Party (PRP) which shared votes with Great Nigerian Peoples' Party (GNPP) and lastly, National Party of Nigeria (NPN) in the Hausa-Fulani speaking areas and eventually produced the executive president in the name of Alhaji Shehu Shagari.

Unfortunately, this election was a replica of the previous elections conducted in Nigeria. In this election, the military played a dubious role and then enthroned unpopular leader through election rigging even the court nullified Chief Awolowo's challenge against the election. Generally, the government (Shagari's regime) performances in the social, economic and political arenas were poor.

According to (Diamond, (1988) Falola and Ihonvbere, (1985) there was gross administrative inefficiency, mass corruption and galloping rate of inflation, while food and other essential commodities became very scarce. Ribadu (2006) described Shagari's administration to be bedevilled with profligacy, wantom waste, political thuggery and coercion... disrespect for rule of law... bare faced, free for all looting of public funds through white elephant project.

In the works of Falola \& Ihonvbere (1985:207); Diamond (1988:67), and Joseph (1987) who described Shagari's led NPN administration as very inefficient; there was massive corruption in the government; politicians were outright rapacious and merciless in the loot for wealth; prominent commodities (food) were scarce; the economy was battered and shattered; and elitist projects were pursued to the consummate neglect of the people's interests. Shagari's NPN (ruling party) having more access to the national resources, excelled of course, in this rape of public wealth. But the other four parties were also involved in the scramble for the national cake. The parties made sure that in the states where they were in charge public funds were diverted to the parties and private accounts as subsequently revealed by panels of enquiries after the overthrow of the politicians. The people were dissatisfied and agitated for a change of government.

In 1983, another election was held and NPN won using a tremendous rigging. For instance, the ruling political party (National Party of Nigeria) used all kinds of manoeuvre to regain their position since they contested as incumbents.

Jinadu (2007) states, Judging from these periods, one will conclude that the 1979 figures were also inflated. As a result of these manipulations from the ruling party and electoral body, violence which was witnessed in the first republican elections re-surfaced its ugly head. Once again, this eventually generated so much violence in the various states to rationalize the military coup of December 1983 which subsequently, brought to the end of second republic.

\subsection{Military Intervention}

Four years after independence, Nigeria had a democratic election in 1964 and installed a parliamentary system of government led by Tafawa Belewa and Dr. Nnamdi Azikiwe. Anugwom (2001) posits: Since independence, the military has dominated Nigeria's politics and can be hold responsible for the political instability, economic and social underdevelopment of the nation. It is important to note that apart from the first republic in 1963 that came into existence as Nigeria got their independence from the British, the military has acted as both the midwife and the 
destroyer of democracy in Nigeria, with the of the election conducted democratically in 1979, the military has displayed a markedly half-hearted effort to install democracy in the 1990's while terminating such steps in mid-stride in 1966, 1983 and 1993.

\subsubsection{Nzeogwu's Coup of 1966}

Democracy promotes periodic elections and before a government is instituted, there must be competitive free and fair election. Unfortunately, the military in 1966 violated this principle as it staged a coup against a democratically elected government. The first military coup that toppled the Parliamentary system government of Alhaji Tafawa Belewa and Dr. Nnamdi Azikiwe (1960 to 1966) was led by Major Kaduna Nzeogwu. The coup executors claimed to have purity of purpose, as the plotters were desperate to stop ethnic violence and corruption in Nigeria. The architects of this coup were mainly of Igbo speaking tribe. This made their motivations a suspect from other tribes. Army officers from the north were of the view that their action was primarily meant to purge them from their ranks, and give more room for the Igbos to run Nigeria. Though, General Ironsi who was a senior officer to Major Nzeogwu and also an Igbo brother assumed the leadership and refuted the claims from his northern counterparts in his broadcast across Nigeria in the wake of the military takeover and posited that the military government of the republic of Nigeria wishes to state that it has taken over the interim administration of the republic of Nigeria following the invitation of the council of ministers of the last government for the army to do so. It worthy to note that the coup witnessed so much bloodshed and this also abrogates the epitome of fundamental human rights upon which democracy is built.

\subsubsection{Buhari and Democracy}

Major General Muhammadu Buhari's emergence was seen as a huge blow to the new democratic government as his coup removed a civilian government of Alhaji Shehu Shagari in 1983. The regime of Shehu Shagari came at the time of oil boom in Nigeria. As a result of the opportunities provided by the oil wealth flowing into Nigeria during his re-election, the administration of Shehu Shagari was massively corrupt and ineffective. The government used most of the oil money on white elephant projects and some were stolen by corrupt officials or what Ribadu (2006) described as "corrupt public servant and others in the private sector before the nation, masquerading as captains of business and power brokers with tainted and stolen wealth and demanded the rest of us to kowtow before them".

To checkmate the activities of the previous administration, General Buhari who became the new Head of state, launched a "war against indiscipline" which actually met with initial approval, but its repressiveness brought to the end of the popularity of this administration as it was overthrown in another military coup that brought General Ibrahim Babangida on the sit of power in 1985

\subsubsection{Babangida and Democracy}

When General Babangida assumed office in August 1985, he saw corruption as a legitimate tool of governance and used it extensively to shore up support. The regime of Babangida came up with an agenda of returning power to a civilian administration but the truth was that the regime in earnest was not ready to relinquish power as the administration embarked on political manoeuvres to keep hold of power. Hutchful (1998) buttresses this argument thus:

The transition to democracy was preceded by attempts at military reform, the military regime also retained tight control over power, permitting no discussion or input by the civilians. The domain of military reform was seen as the exclusive preserve of the military hierarchy. The process of self-reform allowed the military to retain the initiatives on the part of in-coming civilian governments, and to incorporate the interest of both regime and institution into the reform process. Uncontested control over the military was also seen as necessary for keeping the democratic movement in check and preventing the possible unravelling of the carefully calculated transition (p.606-607).

Referring to the nature of General Babangida's political transition which started in 1987, a nationalist, Okoye (1993) lamented:

Diplomats, newspaper reporters, politicians and administrators alike were all fascinated by the baffling ambivalence of Babangida's behaviour; the mixture of pretentious arrogance with the adroit exercise of imperial power, the commingling of callousness and calmness, impatient, arrogant and audacious, he was a great manipulator of power and (had) resources to achieve his ends... Babangida's tragedy is that, in time, he so outgrew his colleagues in guile and omnipotence and omniscience and, like Hitler, even began to believe his own propaganda lies (p.6).

As the pressure mounted from the campaign for democracy coalition and other democratic forces, Babangida accepted to a transition to democracy.

Two political parties were imposed on Nigerians by the military administration in power. The Social Democratic Party (SDP) and Chief M.K.O. Abiola was the party's flag bearer. The National Republican Convention (NRC) with the flag 
bearer in the name of Alhaji Bashir Tofa. There was doubt that two party system in the third republic meant to replace the multi-party of the second republic would succeed.

Nigerians saw this election as the only hope to eradicate military administration in their body polity and went to the pools in June 12, 1993 to support democratic emergence. After the election, Chief M.K.O. Abiola won the election on the plat form of the Social Democratic Party (SDP) convincingly and accumulated 58 percent of the total votes cast.

The annulment of this election's result threatens the political stability and unity of Nigeria. As a measure to reduce tension that gripped the country, General Ibrahim Babangida stepped aside and handed over the power to an Interim Government led by Ernest Shonekan but this was seen by many as a gimmick because four months later, another military took over in November 1993, and this time, led by General Sani Abacha.

Frankly, it's clear that a great percentage of military leaders who have tasted political power hardly relinquish same. In their quest to remain in the office, they have humiliated both political leaders and human rights activists, while many were held in detention without trails and many fled to exile. Example of human right violation by the military was obvious during Gen.Abacha's regime. One of the Ogoni leaders (Ken Saro-Wiwa) was sentenced to death by hanging because he supported the Movement for the Survival of Ogoni People (MOSOP), which many saw as a Just movement. His death infuriated the International Communities and some imposed either political or economic sanction on Nigerians. For instance, in 1995, Commonwealth of Nations which Nigeria is a member, suspended the membership of Nigeria and the privileges accruing to member nations were denied to Nigerians.

General Abacha in 1993 came up with the promise that he will return power to a democratically civilian administration but what was witnessed was violation of human rights, prolongation of his tenure until he died in the office. CultureGrams (2006) described Abacha regime in this manner:

Abacha dissolved democratic institutions and declared himself ruler of Nigeria. Human-rights abuses, corruption, and oppression became Abacha's hallmarks. Strikes and unrest failed to force him from power. International pressure even failed to stop the 1995 execution of nine activists who had campaigned against oil industry damage to Ogoni lands. The Commonwealth suspended Nigeria's membership. Abacha promised a return to democracy by the end of 1998 but allowed only five loyal parties to register in legislative elections. He then ordered all five parties to nominate him as their presidential candidate. When Abacha died of a heart attack in June 1998, the nation celebrated and then waited to see whether his successor, General Abdulsalam Abubakar, would follow in his footsteps. (p.130). (Note 2).

\section{Findings}

Nigeria has tried to consolidate democracy but has failed to achieve any meaningful result due to lack of good governance. Governance, bane on Nigerian democracy. According to Eyinla (2000:22), good governance means accountability, security of human rights and civil liberties, devolution of powers and respect for local autonomy, which all constitute a challenge to democratic regimes. Simbine (2000:17) concurs that good governance has been closely linked to 'the extent which a government is perceived and accepted as legitimate, committed to improving the public welfare and responsive to the needs of its citizens, competent to ensure law and order and deliver public services, able to create an enabling policy environment for productive activities; and equitable in its conduct'. It is unfortunate that, negligence to the rule of law resulted to the violations of human right, election riggings, politics of godfatherism, money politics, administrative ineptitude, electoral malpractices, political assassinations and incessant changes in government and all these have wrecked havoc on the Nigerian political stability.

Democracy in Nigeria has suffered a serious blow reasons emanating from ethnic politics, electoral malpractices, military interventions and political assassinations. Ethnicity possesses serious threat to Nigeria's democracy in such a way that in the first republic, every major ethnic group fielded her own candidate during the Presidential election and the struggle for who should control the government clouded the oneness and unity of Nigeria and this made the election a do or die affair.

Uwazuike and Akinola (1989) captured this finding. Severely limited in their capabilities to integrate the components of that great diversity of societies known as Nigeria. The NPC was the party of the Hausa-Fulani-Kanuri in the North, and did not extend its membership to the South; The AG more or less represented the Yorubas in the West; while the NCNC drew its support largely from the Ibos in the East (p.114).

Military interventions and corrupt leaders in Nigerian politics have negated the chances of democracy. From 1960 to 1999, the country recorded six military coups and two of which overthrew democratically elected governments. Majority of the military Heads of state produced in those regimes had no regards for the common man but only came to power for self accumulation of wealth. Evidence shown in the discussion of this work blamed the military leadership for the situation Nigeria is into today as the country lacks virile democracy. Even democratically elected leaders are not exempted from this mess as Sagagi (2006) described them as having one pattern of thinking and 
action... to be in power as long as it takes. Nigerian leaders or politicians in general have only one plan, one mission, and one goal; winning an election, settling scores, and (self-enrichment through fraudulent practices).

\section{Recommendations}

In order to avoid bad governance and failures of leaders, any candidate vying for leadership in Nigeria should be extensively checked before they could be allowed to lead; those who are found wanting on this leadership checks should be barred from any leadership position in Nigeria. Added to this, responsible Nigerians living abroad with charisma should be given a fair chance to contribute their quota to the governance of the country to enhance the efficiency and effectiveness of both economic development and virile democracy in the country.

The structure of democracy must be political, virile, dynamic and engaging the society and responsible media. Elections in Nigeria should be taken serious and it should as a matter of fact, carried out in the interest of the populace. Election riggings/electoral manipulation are enemies of democracy and to enhance democratic success, free and fair elections should be allowed to triumph. Where there are election manipulations and riggings, government should allow the judiciary the power to declare anyone who emerges a winner through election rigging illegal. People should try as much as possible to reduce election riggings by making sure that their votes are counted before the returning officer.

Democracy need not be too expensive as a form of government. What is gained is unity, freedom, consensus, stability, commitment and development in a truly democratic society easily outweighs the costs of maintaining and sustaining the structures of democracy. Effective democratic process provides checks and balances, which limit the abuses of power, corruption, oppression, dictatorial and the authoritarian tendencies.

\section{Conclusion}

A holistic view of the observations above leads us to the fundamental question as to ascertain how democratic the entity (Nigeria) really is. Frankly speaking, some essential improvement has taken place in Nigeria body polity via formalistic level of multi-partyism and periodic elections but time shall tell when these improvements will help bring the dividends of democracy which include rising legitimacy of the state; improve standard of living for the majority; improve fundamental human rights in its totality; all culminating in popular empowerment, participation and enhanced environment conducive for democratic development.

Nigeria's effort to develop democratic governance has been thwarted by corrupt leaders and military dictatorship and these have resulted into the embezzlement of government fund, electoral and election manipulations, incessant political killings, coups and counter coups, and wrong policies which have marred the chances of democratic development. Both civilian and military regimes have not done well in shaping the face of democracy that will enhance conducive environment for the transformation of Nigeria's political instability into a virile democratic development. Democracy in Nigeria will take shape if some of its principles are applied in her body polity. Nigeria needs a periodic election which will be devoid of riggings and incessant manipulations. If the system is free and fair, the citizens will be attracted to participate in politics but it is unfortunate that the adverse is the case. We still believe that in future, democracy will finally emerge if those indices that confront negatively Nigeria's democracy are put in check.

\section{References}

Agbaje, A. \& Adejumobi, S.(2006). Do votes count? The travails of electoral politics in Nigeria. Journal of African development. Vol.XXXI, No.3

Ajani, J. (2001). A Political Philosophy Misunderstood. Daily Vanguard. December 25.

Akinola, A. (1989). A critique of Nigeria’s Proposed Two-Party System. Journal of Modern African Studies, 27(1). (p. 114).

Alliance For Democracy (2005). Political Killings, Threat to Democracy. The Nigerian Observer, August 8, (p.3).

Anifowose, R. (1982). Violence and Politics in Nigeria: The Tiv and Yoruba Experience New York, London, Lagos and Enugu: Nok.

Anugwom, E. (2001). The Military, Ethnicity and Democracy in Nigeria. Journal of Social Development in Africa Vol.16 No.2.

Awolowo, O. (1966). The Authorbiolography of Chief Obafemi Awolowo. Cambridge: University Press.

Butts, K.H. \& Metz, S. (1996). Armies and Democracy in the New Africa. Lessons from Nigeria and South Africa. Diane Publishing Co. (p. 2).

CultureGrams. (2006). People: The world you. Salt Lake City, UT: Hiller. 
Dahl,R. (1991). Modern Political Analysis. New Delhi: Prentice Hall. (p.72-75).

Diamond,L.(1988). The 1983 General Elections. In Ayeni, and V.Soremekun, K. (eds) Nigeria's Second Republic. Lagos: Daily Times publication (p.67).

Diamond, L., Linz, J.J, Lipset, S.M. (1989). Democracy in Developing Countries. Boulder, Co: Lynne Rienner.

Dudley,B.(1981). The Nigerian Elections of 1979: The Voting Decision. Journal of Commonwealth and Comparative Politics, Vol. XIX, No.3.

Eyinla, B. (2000). The Political Transition and the Future of Democracy in Nigeria. Politica Science Review,Vol.1 No.1.

Falola, T. \& Ihonvbere, J.(1985).The Rise and Fall of Nigeria's Second Republic 1979-1984. London: Zed Books.

Hutchful, E.\& Abdoulaye, B.(1998). The military and militarism in Africa: Dakar: CODESRIA.

Igbinovia,P.E.(2003). The Criminal in All of Us: Whose ox have we not taken. University of Benin Inaugural Lecture Series 71.University of Benin Press (p.143).

Jinadu, L.A. (2007). Historical Analysis of Elections and Election Management in Nigeria. Paper prepared for presentation of the Civil Society Organisation meeting on electoral reform organized by the Open Society Initiative for West Africa (OSIWA) in Abuja, Nigeria, Oct. 19.

Joseph, R.A.(1987). Democracy and Prebendal Politics in Nigeria: The rise and the fall of the second republic. Cambridge University Press.

Okoye, M. (1993). Is it goodbye general? African Guardian: October 18.

Omotola, J.S. (2007). Democratization, Good Governance and Development in Africa: The Nigerian Experience. Journal of Sustainable Development in Africa. Vol.9, No 4.

Post, K. \& Vickers, M.(1973). Structure and Conflict in Nigeria 1960-65. London: Heinemann.

Ribadu, N. (2006). Corruption: The trouble with Nigeria. http://www.gamji.com/artic/5000/NEWS 5530.htm.

Sagagi, M.S.(2006). Re-inventing Nigeria's Political Process. Retrieved July 25, 2006 From $\mathrm{http} / / /$ www.weeklytrust.com/nigeria 12072002.htm.

Simbine, A.T. (2000). Citizen's Disposition towards Governance and Democratic Rule in Nigeria. NISER Monograph Series, No.15.

Sorensen, G. (1993). Democracy and Democratization. Boulder co: Westview Press.

Umez, B.N.(2000). Nigeria: Real Problems, Real Solutions. The Tragedy of a Value System in Nigeria: Theories and Solutions. Snaap Press.

Note 1. Some cases of unresolved political assassinations in Nigeria 1986-1999.

\begin{tabular}{|c|c|c|c|c|}
\hline NAMES & DATE & LOCATION & MODE & OUTCOME \\
\hline Dele Giwa & Oct 191986 & Lagos & Parcel bomb & Unresolved \\
\hline Babatunde Elegbede & May 5,1994 & Lagos & Shot & Unresolved \\
\hline Lekan Owolabi & March 1995 & Lagos & Shot & Unresolved \\
\hline Captain Tunde Ashafa & June 11,1995 & Lagos & Shot & Unresolved \\
\hline Mr. Alfred Rewane & Oct.6 1995 & Lagos & Shot & Unresolved \\
\hline David Izegwere & Dec. 1995 & Lagos & Shot & Unresolved \\
\hline Kayode Awosanya & Jan.1995 & Lagos & Shot & Unresolved \\
\hline Tajudeen Abiola (mrs.) & Feb.9 1996 & Lagos & Shot & Unresolved \\
\hline Alhaji Sama Kano & April 8, 1996 & Lagos & Shot & Unresolved \\
\hline Admiral Olu O. & May 22,1996 & Lagos & Shot & Unresolved \\
\hline Irene Obodo (mrs.) & June 1996 & Lagos & Shot & Unresolved \\
\hline Alhaji Kudirat Abiola & June 4,1996 & Lagos & Shot & Unresolved \\
\hline Chief Adejola Balogun & June 15,1996 & Lagos & Shot & Unresolved \\
\hline Esther A.Tejuoso (mrs.) & Sep.19,1996 & Lagos & Shot & Unresolved \\
\hline Alhaji Suliat Adedeji & Nov.14,1996 & Ibadan & Shot & Unresolved \\
\hline Toyin Onagoruwa & Dec.1996 & Lagos & Shot & Unresolved \\
\hline Engr.Adesoji A. Dina & Sep.1998 & Lagos & Shot & Unresolved \\
\hline Kola Tokunbo & Jan.31,1999 & Lagos & Shot & Unresolved \\
\hline Sunday Ugwu & Sep. 15,1999 & Enugu & Shot & Unresolved \\
\hline
\end{tabular}

Source: Adapted from Igbinovia, E (2003) 
Note 2. Civilian and Military Regimes in Nigeria by Year, 1960-1999.

\begin{tabular}{|c|c|c|}
\hline $\begin{array}{l}\text { Year } \\
\text { Regime }\end{array}$ & Regime & Year \\
\hline $\begin{array}{l}1960 \\
\text { civilian }\end{array}$ & civilian & 1980 \\
\hline $\begin{array}{l}1961 \\
\text { civilian }\end{array}$ & civilian & 1981 \\
\hline $\begin{array}{l}1962 \\
\text { civilian }\end{array}$ & civilian & 1982 \\
\hline $\begin{array}{l}1963 \\
\text { military }\end{array}$ & civilian & 1983 \\
\hline $\begin{array}{l}1964 \\
\text { military }\end{array}$ & civilian & 1984 \\
\hline $\begin{array}{l}1965 \\
\text { military }\end{array}$ & civilian & 1985 \\
\hline $\begin{array}{l}1966 \\
\text { military }\end{array}$ & military & 1986 \\
\hline $\begin{array}{l}1967 \\
\text { military }\end{array}$ & military & 1987 \\
\hline $\begin{array}{l}1968 \\
\text { military }\end{array}$ & military & 1988 \\
\hline $\begin{array}{l}1969 \\
\text { military }\end{array}$ & military & 1989 \\
\hline $\begin{array}{l}1970 \\
\text { military }\end{array}$ & military & 1990 \\
\hline $\begin{array}{l}1971 \\
\text { military }\end{array}$ & military & 1991 \\
\hline $\begin{array}{l}1972 \\
\text { military }\end{array}$ & military & 1992 \\
\hline $\begin{array}{l}1973 \\
\text { military }\end{array}$ & military & 1993 \\
\hline $\begin{array}{l}1974 \\
\text { military }\end{array}$ & military & 1994 \\
\hline $\begin{array}{l}1975 \\
\text { military }\end{array}$ & military & 1995 \\
\hline $\begin{array}{l}1976 \\
\text { military }\end{array}$ & military & 1996 \\
\hline $\begin{array}{l}1977 \\
\text { military }\end{array}$ & military & 1997 \\
\hline $\begin{array}{l}1978 \\
\text { military }\end{array}$ & military & 1998 \\
\hline $\begin{array}{l}1979 \\
\text { civilian }\end{array}$ & civilian & 1999 \\
\hline
\end{tabular}

Source: Umez, B.N (2000) 